\title{
PENGGUNAAN PERMAINAN LEGO DALAM BIDANG PENGEMBANGAN KOGNITIF UNTUK MENINGKATKAN KREATIVITAS ANAK USIA DINI DI PPT PERMATA BUNDA KECAMATAN WONOCOLO SURABAYA
}

\author{
Berda Asmara \\ Universitas Nahdlatul Ulama Surabaya \\ e-mail: asmaraberda@unusa.ac.id
}

\begin{abstract}
Abstrak: Pendidikan anak usia dini atau usia prasekolah adalah tempat bagi anak untuk mengantarkan perkembangan dan pertumbuhan anak dalam meningkatkan kecerdasan, keterampilan, daya cipta, pengetahuan, dan kemandirian sejak dini dengan cara bermain sambil belajar atau belajar secara bermain. Melalui pembelajaran PAKEM dapat dilaksanakan kegiatan bermain lego merupakan media permainan yang sangat menarik bagi anak-anak. Penelitian ini bertujuan untuk mengetahui penggunaan permainan lego dalam pengembangan kognitif untuk meningkatkan kreativitas anak usia dini di PPT Permata Bunda Kecamatan Wonocolo Surabaya. Penelitian ini menggunakan metode tanda bintang observasi. Dan dalam penelitian ini yang diteliti adalah anak usia dini di PPT Permata Bunda Kecamatan Wonocolo Surabaya. Bidang pengembangan kognitif Semester I kelompok A dan B menggunakan tema "Diri Sendiri" dengan menggunakan sistem kolaborasi yaitu guru kelompok A dan B dalam Semester II. Hasil penelitian ini adalah hasil pemantauan observasi I belum baik, karena anak baru mengenal permainan lego belum aktif sehingga kurang kreatif. Hasil pemantauan observasi ke II hasilnya baik aktivitas dan kreativitas anak mulai meningkat, karena anak mulai terbiasa menggunakan permainan lego. Hasil pemantauan observasi ke III hasilnya baik karena anak aktif dan kreatif. Kesimpulan dari penelitian ini adalah penggunaan permainan lego dalam pengembangan kognitif dapat meningkatkan kreativitas anak usia dini di PPT Permata Bunda Kecamatan Wonocolo Surabaya.
\end{abstract}

Kata kunci: permainan lego, pengembangan kognitif, kreativitas

Abstract: Early childhood education or preschool age is a place for children to deliver the development and growth of children in improving intelligence, Skills, creativity, knowledge, and early independence by playing while learning or learning in play. Through PAKEM learning can be performed lego playing activities is a media game that is very interesting for children. This study aims to determine the use of lego games in cognitive development to improve the creativity of early childhood in PPT Permata Bunda Wonocolo District Surabaya. This study uses the method of observation stars. And in this study studied is the early childhood in PPT Permata Bunda Wonocolo District Surabaya. The cognitive development field of Semester I of group A and B uses the theme "Self" by using collaboration system that is group A and B teachers in Semester II. The result of this research is observation result I not yet good, because the new child know lego game not active so less creative. The results of observation monitoring to the second result both activities and creativity of children began to increase, because children are getting used to using the game lego. The result of observation monitoring to III is good because the child is active and creative. The conclusion of this research is the use of lego game in cognitive development can improve creativities early child in PPT Permata Bunda Wonocolo Subdistrict Surabaya.

Keywords: lego game, cognitive development, creativity 


\section{PENDAHULUAN}

Pendidikan yang diberikan sejak Dini adalah sangat penting, terutama pada Pendidikan Anak Usia Dini, meskipun tampaknya orang beranggapan bahwa pendidikan di PAUD dalam suasana ringan dan penuh ceria. Sebabnya adalah karena di PAUD, anak-anak pertama kali berkenalan dengan lingkungan yang lebih luas dari lingkungan keluarga sendiri. Oleh karena itu PAUD merupakan salah satu bentuk satuan pendidikan prasekolah yang bertujuan untuk membantu meletakkan dasar ke arah perkembangan sikap, pengetahuan, keterampilan dan daya cipta yang diperlukan oleh anak didik dalam menyesuaikan diri dengan lingkungannya dan untuk pertumbuhan serta perkembangan selanjutnya.

Menurut para ahli psikologi, usia dini (08 tahun) sangat menentukan bagi anak mengembangkan potensinya. Usia ini sering disebut "usia emas" (the golden age) yang hanya datang sekali dan tidak dapat diulangi lagi, yang sangat menentukan untuk pengembangan kualitas manusia selanjutnya. Berdasarkan hasil penelitiannya mengemukakan bahwa perkembangan intelektual anak terjadi sangat pesat pada tahuntahun awal kehidupan anak. Sekitar 50\% variabilitas kecerdasan orang dewasa sudah terjadi ketika anak berusia empat tahun. Peningkatan $30 \%$ berikutnya terjadi pada usia 8 tahun, dan $20 \%$ sisanya pada pertengahan atau akhir dasawarsa kedua (Depdiknas, 2008:1).

Azhar Arsyad (2009:67) berpendapat bahwa Pembelajaran yang efektif memerlukan perencanaan yang baik. Media yang akan digunakan dalam proses pembelajaran itu juga memerlukan perencanaan yang baik. Meskipun demikian, kenyataan di lapangan menunjukkan bahwa seorang guru memilih salah satu media dalam kegiatannya di kelas atas dasar pertimbangan antara lain (a) ia merasa sudah akrab dengan media yang diterimanya, (b) ia merasa bahwa media yang dipilihnya dapat menggambarkan dengan lebih baik daripada dirinya sendiri, (c) media yang dipilihnya dapat menarik minat dan perhatian siswa, serta menuntunnya pada penyajian yang lebih terstruktur dan terorganisasi.

Menurut Zainal Aqib (2009:30) Pembelajaran di PAUD mempunyai prinsip "Bermain sambil belajar, belajar seraya bermain". Dengan bermain anak menemukan dan mendapatkan pengalaman dari dirinya sendiri, orang lain dan lingkungannya. Belajar dengan bermain memberikan kesempatan pada anak untuk memanipulasi, mengulang-ulang dan menemukan sendiri serta bereksplorasi dan mempraktikkan sehingga anak mendapatkan bermacam-macam konsep serta pengertian yang banyak. Permainan berhitung merupakan bagian matematika, yang diperlukan untuk menumbuhkembangkan keterampilan berhitung sangat berguna bagi kehidupan sehari-hari. Selain itu permainan berhitung juga diperlukan untuk membentuk sikap logis, kritis, cermat, dan disiplin pada diri anak.

Pembelajaran pada PAUD dilakukan dengan bermain dan tidak menargetkan pada suatu hasil, tetapi pada prosesnya. Peneliti melakukan pengamatan terhadap permasalahan yang terjadi, bahwa salah satu kemampuan yang harus ditingkatkan adalah kemampuan kognitif yang salah satu indikatornya adalah mengenal konsep bilangan. Dengan banyaknya orang tua menghendaki agar anak-anak mereka segera memiliki kemampuan berhitung di samping membaca dan menulis, maka dalam meningkatkan pengembangan kognitif tersebut permainan lego diharapkan dapat mengembangkan aspek kognitif anak dengan bentuk permainan efektif yang menyenangkan.

Penggunaan permainan lego di PAUD khususnya di PPT Permata Bunda merupakan hal yang sangat penting dan bermanfaat bagi kehi- 
dupan sehari-hari, terutama untuk melatih kreativitas anak didik yang merupakan dasar bagi pengembangan seni kreativitas. Dengan kata lain, penggunaan permainan lego di PAUD diperlukan untuk mengembangkan pengetahuan dasar kognitif, sehingga anak secara mental siap mengikuti pembelajaran matematika lebih lanjut di sekolah dasar. Seperti pengenalan konsep bilangan, lambang bilangan, warna, bentuk, ukuran. Selain itu permainan lego juga diperlukan untuk membentuk sikap logis, kritis, kreatif pada diri anak.

Maka dari itu penulis sangat tertarik untuk mengadakan penelitian tentang "Penggunaan permainan lego dalam bidang pengembangan kognitif untuk meningkatkan kreativitas anak usia dini di PPT Permata Bunda Kecamatan Wonocolo Surabaya".

\section{Rumusan Masalah}

Berdasarkan pemaparan latar belakang tersebut, rumusan masalah dalam penelitian ini adalah bagaimana penggunaan permainan lego dalam bidang pengembangan kognitif untuk meningkatkan kreativitas anak usia dini di PPT Permata Bunda Kecamatan Wonocolo Surabaya?

\section{Tujuan Penelitian}

Berdasarkan pemaparan latar belakang tersebut, rumusan masalah dalam penelitian ini adalah bagaimana penggunaan permainan lego dalam bidang pengembangan kognitif untuk meningkatkan kreativitas anak usia dini di PPT Permata Bunda Kecamatan Wonocolo Surabaya?

\section{Manfaat Penelitian}

Manfaat dari penelitian ini adalah sebagai berikut.
1. Untuk memiliki ketelitian, konsentrasi, abstraksi, dan daya apresiasi yang tinggi

2. Mengetahui peningkatan kreativitas anak.

3. Untuk meningkatkan daya pikir anak

\section{KAJIAN PUSTAKA}

Dalam kaitan dengan permasalahan yang telah penulis kemukakan, maka teori-teori yang akan penulis sajikan adalah teori dari berbagai pendapat ahli untuk membahas permasalahan yang berkaitan dengan penggunaan permainan berhitung dan kreativitas anak adalah sebagai berikut.

\section{A. Anak Usia Dini}

Anak usia dini berdasarkan pendapat dari Berk (dalam Sujiono, 2009: 6), adalah sosok individu yang sedang menjalani suatu proses perkembangan dengan pesat dan fundamental bagi kehidupan selanjutnya. Anak usia dini ini berada pada rentang usia $0-8$ tahun. Pada masa ini proses pertumbuhan dan perkembangan dalam berbagai aspek sedang mengalami masa yang cepat dalam rentang perkembangan hidup manusia. Proses pembelajaran sebagai bentuk perlakuan yang diberikan pada anak harus memperhatikan karakteristik yang dimiliki setiap tahapan perkembangan anak.

Pada hakikatnya anak adalah makhluk individu yang membangun sendiri pengetahuannya. Anak lahir dengan membawa sejumlah potensi yang siap untuk ditumbuhkembangkan asalkan lingkungan menyiapkan situasi dan kondisi yang dapat merangsang kemunculan dari potensi yang tersembunyi tersebut (Sujiono dan Sujiono, 2010:21).

1) Aspek Perkembangan Anak Usia Dini

Catron dan Allen (dalam Sujiono dan Sujiono, 2010: 22) menyebutkan bahwa terdapat 6 
(enam) aspek perkembangan anak usia dini, yaitu kesadaran personal, pengembangan emosi, membangun sosialisasi, pengembangan komunikasi, kognisi, serta kemampuan motorik.

2) Karakteristik Perkembangan Anak Usia Dini Coughlin (Dalam Sujiono dan Sujiono, 2010: 24-25) menjelaskan ciri-ciri umum anak dalam rentang usia 3-6 tahun.

a) Anak-anak pada usia tersebut menunjukkan perilaku yang bersemangat, menawan dan kasar pada saat tertentu.

b) Anak mulai memahami dunia di sekeliling mereka walaupun mereka masih sulit membedakan khayalan dan kenyataan.

c) Pada suatu situasi tertentu anak mampu bekerjasama dengan orang lain, pada saat yang lain anak menjadi pengatur dan penuntut.

d) Anak mampu mengembangkan kemampuan berbahasa dengan cepat.

e) Anak memiliki tenaga besar tetapi daya konsentrasinya pendek.

3) Perkembangan Kognitif

Menurut pendapat Pamela Minet yang terangkum dalam modul PLPG (Pendidikan dan Pelatihan Profesi Guru), (2011:1), mendefinisikan bahwa perkembangan intelektual adalah sama dengan perkembangan mental, sedangkan perkembangan kognitif adalah perkembangan pikiran. Pikiran adalah bagian dari proses berpikir dari otak. Kognitif adalah proses yang terjadi secara internal di dalam pusat susunan saraf.

4) Masa Peka berhitung Anak

Perkembangan masa peka berhitung pada anak dipengaruhi oleh faktor kematangan dan belajar. Apabila anak sudah menunjukkan masa peka (kematangan) untuk berhitung, maka orang tua dan guru di TK harus tanggap, untuk segera memberikan layanan dan bim- bingan sehingga kebutuhan anak dapat terpenuhi dan tersalurkan dengan sebaik-baiknya menuju perkembangan kemampuan berhitung yang optimal. Anak usia TK adalah masa yang sangat strategis untuk mengenalkan berhitung di jalur matematika, karena usia TK sangat peka terhadap rangsangan yang diterima dari lingkungan. Rasa ingin tahunya yang tinggi akan tersalurkan apabila mendapat stimulasi/rangsangan/motivasi yang sesuai dengan tugas perkembangan-nya Depdiknas (2007:4).

5) Perkembangan Awal menentukan Perkembangan Selanjutnya.

Lima tahun pertama dalam kehidupan anak merupakan peletak dasar bagi perkembangan selanjutnya, pernyataan ini diadaptasi dari pendapat Hurlock (dalam Depdiknas, 2007: 7), anak yang mengalami masa bahagia berarti terpenuhinya segala kebutuhan baik fisik maupun psikis di awal perkembangannya diramalkan akan dapat melaksanakan tugas-tugas perkembangan selanjutnya. Piaget juga mengatakan bahwa untuk meningkatkan perkembangan mental anak ke tahap yang lebih tinggi dapat dilakukan dengan memperkaya pengalaman anak terutama pengalaman konkret, karena dasar perkembangan mental adalah melalui pengalaman-pengalaman aktif dengan menggunakan benda-benda di sekitarnya. Pendidikan di Lembaga PAUD sangat penting untuk mencapai keberhasilan belajar pada tingkat pendidikan selanjutnya.

\section{B. Permainan dan Bermain}

Menurut Comenius, pendidikan harus dimulai sejak usia dini. Pada dasarnya pendidikan adalah baik oleh karena itu pendidikan seharusnya dapat memberikan pengalaman belajar yang baik pula. 
John Locke berpendapat bahwa anak merupakan kertas putih yang bersih dan lingkunganlah yang membentuk baik buruknya seorang anak.

Menurut Tientje (2000) kecerdasan perlu digali dan ditumbuhkembangkan dengan cara memberi kesempatan kepada anak untuk mengembangkan secara optimal potensi-potensi yang dimiliki atas upayanya sendiri.

Menurut Hughes (1999) ada lima karakteristik bermain yang esensial yaitu: meningkatkan motivasi, pilihan bebas, non-linier, menyenangkan dan pelaku terlibat secara aktif.

Bromley (1992:216) berpendapat bahwa strategi yang digunakan harus menyediakan dengan tepat sesuai minat yang dibutuhkan anak, juga melibatkan anak dan situasi yang berbeda dalam kelompok kecil, kelompok besar, dan secara individu.

Sedangkan menurut pandangan kaum konstruktivistik, belajar merupakan suatu proses pembentukan pengetahuan, afektif dan psikomotor. Pembentukan ini harus dilakukan oleh siswa, siswa harus aktif melakukan kegiatan, aktif berpikir, menyusun konsep, dan memberi makna tentang hal-hal yang dipelajari (Budiningsih, 2005:58).

Menurut Sudjana (2001:2) belajar merupakan suatu proses yang ditandai dengan adanya perubahan pemahaman, sikap dan tingkah laku, keterampilan, kecakapan dan kemampuan, daya reaksi, daya penerima aspek-aspek lain yang ada pada individu.

\section{Kreativitas Anak \\ 1) Pengertian Kreativitas}

a. Menurut Hurlock yang diterjemahkan oleh Dr. Med Meitasori Tjoncrasa (1993:2) bahwa:
"Kreativitas adalah sebagai kreasi sesuatu yang baru dan orisinal secara kebetulan"

b. Menurut Utami Munandar (1985:47) bahwa: "Kreativitas adalah kemampuan untuk membuat kombinasi baru berdasarkan data, informasi, atau unsur-unsur yang ada".

Maka dapat diambil kesimpulan tentang pengertian kreativitas yang sudah dipaparkan oleh beberapa para ahli yaitu Kreativitas adalah untuk menciptakan suatu kreasi dengan gagasan-gagasan yang baru dan orisinal.

\section{2) Ciri-ciri Kreativitas Anak Usia Dini}

Anak pra-sekolah dalam perilakunya mencerminkan ciri-ciri anak yang kreatif, dapat dibuktikan ketika mereka atau anak usia dini memiliki apa yang disebut kreativitas alamiah antara lain mereka senang menjejaki lingkungannya, mengamati dan mendekati segala macam tempat atau pojok, seakan-akan senang melakukan eksperimen. Hal ini tampak dari perilakunya senang mencoba-coba.

\section{Perkembangan Kognitif}

Piaget membagi perkembangan kognitif ke dalam empat fase, yang di antaranya:

a. Fase sensori motor (usia 0-2 tahun)

b. Fase praoperasional (usia 2-7 tahun)

c. Fase operasional konkret (usia 7-12 tahun)

d. Fase operasional formal (usia 12 sampai usia dewasa)

Jean Piaget berpendapat dalam sebagaimana yang terdapat dalam modul yang diterbitkan oleh Depdiknas (2007:4), yang menyatakan bahwa kegiatan belajar memerlukan kesiapan dalam diri anak. Artinya belajar sebagai suatu proses membutuhkan aktivitas baik fisik maupun psikis. Selain itu kegiatan belajar pada anak 
harus disesuaikan dengan tahap-tahap perkembangan mental anak, karena belajar bagi anak harus keluar dari anak itu sendiri. Anak usia dini berada pada tahapan pra-operasional konkret yaitu tahap persiapan ke arah pengorganisasian pekerjaan yang konkret dan berpikir intuitif di mana anak mampu mempertimbangkan tentang besar, bentuk dan benda-benda didasarkan pada interpretasi dan pengalamannya (persepsinya sendiri).

\section{METODE PENELITIAN}

\section{Pendekatan Penelitian}

Metode penelitian kuantitatif dapat diartikan sebagai metode penelitian yang berdasarkan pada filsafat positivism, digunakan untuk meneliti pada populasi atau sampel tertentu, teknik pengambilan sampel pada umumnya dilakukan secara random, pengumpulan data menggunakan instrumen penelitian, analisis data bersifat kuantitatif/ statistik dengan tujuan untuk menguji hipotesis yang telah ditetapkan (Sugiyono, 2009: 14).

Metode yang digunakan dalam penelitian ini adalah metode pemberian tugas, yaitu penelitian yang dilakukan terhadap variabel yang datadatanya belum ada sehingga perlu dilakukan proses manipulasi melalui pemberian treatment (perlakuan) tertentu terhadap subjek penelitian yang kemudian diamati dan diukur dampaknya.

\section{Desain Penelitian}

Berdasarkan keterangan di atas, sebelum diberikan perlakuan, peneliti melakukan observasi terhadap kreativitas dan kemampuan kognitif anak didik di PPT Permata Bunda yang terpilih sebagai sampel untuk mengukur kondisi awal.

\section{Subjek Penelitian}

Penelitian ini akan dilaksanakan di PPT Permata Bunda Kecamatan Wonocolo. Sedangkan subyek penelitian ini adalah anak didik PPT Permata Bunda Kecamatan Wonocolo Surabaya dengan jumlah 56 anak. Adapun alasan peneliti dalam penentuan lokasi dan subjek penelitian adalah sebagai berikut.

1. PPT yang ditetapkan sebagai tempat penelitian adalah PPT Permata Bunda Kecamatan Wonocolo yang memiliki jumlah anak 56 dari anak laki-laki 18 anak dan anak perempuan 38 .

2. Subjek penelitian dalam penelitian ini adalah kelompok B, yang memiliki sifat homogen dan karakteristik yang sama (berdasarkan tahap perkembangan anak usia 3-4 tahun), meliputi latar belakang, status sosial ekonomi, adat istiadat, dan kultur yang sama, serta tingkat kemampuan, potensi, maupun kecerdasan yang setara.

\section{Teknik Pengumpulan Data}

Dalam teknik pengumpulan data menurut Sugiyono (2009: 193) terdapat dua hal utama yang memengaruhi kualitas data hasil penelitian, yaitu kualitas instrumen penelitian, dan kualitas pengumpulan data. Kualitas instrumen penelitian berkenaan dengan validitas dan reliabilitas instrumen penelitian dan kualitas pengumpulan data berkenaan dengan ketepatan cara-cara yang digunakan untuk mengumpulkan data.

Untuk mengumpulkan data dalam penelitian ini, maka digunakan beberapa teknik pengumpulan data sebagai berikut.

\section{Observasi/pengamatan}

Menurut Sutrisno Hadi (dalam Sugiyono, 2009: 203) mengemukakan bahwa, observasi 
merupakan suatu proses yang kompleks, suatu proses yang tersusun dari berbagai proses biologis dan psikologis. Dua di antara yang terpenting adalah proses-proses pengamatan dan ingatan. Dalam penelitian ini observasi yang dilakukan untuk mengumpulkan data kreativitas dan perkembangan kognitif sebelum dan sesudah pelaksanaan kegiatan bermain lego.

Observasi dalam penelitian ini menggunakan pedoman pengamatan dengan jumlah item sebanyak 2 aspek yang diamati yakni kreativitas dan perkembangan kognitif. Untuk kreativitas peneliti menilai kemampuan anak dalam menunjukkan inisiatif dalam memilih tema permainan, memosisikan hasil karya secara proporsional. Sedangkan untuk perkembangan kognitif, peneliti menilai kemampuan anak dalam berhitung, mengenal angka dan anak dapat bereksplorasi dengan mengenai hasil karya anak didik.

Hal ini sesuai dengan Tingkat Pencapaian Perkembangan kelompok B usia 3-4 tahun Taman Kanak-kanak dari standar PAUD Permendiknas No. 58 tahun 2009. Sementara posttest (sesudah kegiatan) dilakukan melalui kegiatan bermain lego setelah akhir dari kegiatan.

\section{Dokumentasi}

Metode dokumentasi merupakan metode pengumpulan data yang dilakukan dengan cara melihat catatan yang berhubungan dengan data yang dibutuhkan. Dokumentasi dalam penelitian ini digunakan untuk memperoleh data berupa hal-hal sebagai berikut.

a. RKM, RKH, dan langkah-langkah pembelajaran untuk memperoleh data tentang keberhasilan siklus penelitian yang telah dirancang dan dilakukan.

b. Hasil karya anak melalui kegiatan bermain lego sebagai bahan untuk menilai peman- faatan media dalam menunjang kreativitas dan perkembangan kognitif anak.

Berdasar uraian di atas, maka proses untuk mengumpulkan data melalui metode observasi dan dokumentasi dilakukan pada waktu proses pembelajaran sedang berlangsung.

\section{Instrumen Penelitian}

Instrumen penelitian adalah suatu alat yang digunakan mengukur fenomena alam maupun sosial yang diamati, secara spesifik semua fenomena ini disebut dengan variabel penelitian (Sugiyono, 2009: 148). Instrumen penelitian digunakan untuk mengukur variabel yang akan diteliti, dengan demikian jumlah instrument yang akan digunakan penelitian akan bergantung dari jumlah variabel yang akan diteliti.

Dalam penelitian ini instrument yang digunakan oleh peneliti adalah pedoman pengamatan atau observasi. Kreativitas yang dinilai meliputi indikator dalam menunjukkan inisiatif dalam memilih tema permainan, memosisikan hasil karya secara proporsional. Untuk perkembangan bahasa yang dinilai meliputi indikator dalam berkomunikasi secara lisan, memiliki perbendaharaan kata, memiliki banyak kata-kata untuk mengekspresikan ide pada orang lain, melanjutkan cerita/bercerita mengenai hasil karya.

Variabel kreativitas dan perkembangan kognitif diukur dengan menjumlahkan skor pada lembar observasi dengan teknik pemberian skor. Kisi-kisi instrument observasi terlampir dalam tabel di bawah ini.

\section{Indikator Keberhasilan}

Indikator keberhasilan penelitian ini yakni mampu mendeskripsikan dan menganalisis peng- 
gunaan permainan lego dalam perkembangan kognitif untuk meningkatkan kreativitas anak usia dini.

\section{HASIL PENELITIAN DAN PEMBAHASAN}

\section{Peran Peneliti}

Peneliti menggunakan media/alat pembelajaran "Permainan Berhitung dengan menggunakan lego" yang menurut peneliti sebagai instrumen/alat untuk lebih meningkatkan daya pikir atau kemampuan kognitif pada anak. Dan sekaligus sebagai perencana tindakan kelas, pelaku tindakan, pengamat (observer) dan pelapor hasil penelitian. Jadi peran peneliti mutlak diperlukan selama tindakan berlangsung. Status peneliti di sini adalah sebagai guru kelas B dan subjek penelitian.

\section{Hasil Penelitian}

a. Penelitian dilakukan pada semua anak didik dengan mengamati kemampuan daya pikir masing-masing anak didik.

b. Guru melakukan penelitian selama 30 hari, dengan jadwal 1 hari meneliti 1 anak +4 hari meneliti 2 anak, diselipkan pada materi pelajaran setiap hari kurang lebih 1 anak 10 menit s/d 15 menit waktu istirahat/pulang sekolah.

c. Setelah meneliti masing-masing anak, guru menilai dari hasil kemampuan anak dengan tanda bintang $(\star)$ :

$$
\begin{aligned}
& \star 1=\text { kurang, } \\
& \star 2=\text { cukup, } \\
& \star 3=\text { baik, } \\
& \star 4=\text { sangat baik }
\end{aligned}
$$

Dari hasil penelitian tersebut di atas peneliti menyimpulkan bahwa dengan media/alat pem- belajaran "Permainan Lego" berpengaruh besar terhadap motivasi belajar mengenal angka, guna meningkatkan daya pikir (kemampuan menghitung) anak didik.

Dari kesimpulan data menerangkan:

a. Jumlah anak didik 26 anak, setiap hari meneliti 1-2 anak sampai dengan tanggal 11 Maret 2016.

b. Hasil penelitian menunjukkan nilai yang berbeda tetapi sebagian besar dapat dikatakan baik. Persentase penilaian sebagai berikut. Nilai Bintang 4 (Sangat Baik) sebanyak 13 anak

Nilai Bintang 3 (Baik) sebanyak 09 anak Nilai Bintang 2 (Cukup) sebanyak 04 anak Nilai Bintang 1 (Kurang) sebanyak - anak

c. Waktu penilaian disimpulkan

Anak yang sangat baik kemampuan kognitifnya akan lebih cepat memahami hitungan/angka untuk itu dalam waktu 20 menit yang direncanakan ibu guru anak mampu menunjukkan pemahaman angka 1-5.

Anak yang kemampuan kognitifnya lebih lambat dari waktu yang ditentukan 20 menit, akan mendapat nilai baik/cukup, maka itu waktunya ditambah 5 menit agar pemahaman lebih baik (25 menit).

Anak yang kemampuan kognitifnya kurang, walaupun dalam waktu 25 menit yang telah ditentukan, anak tetap masih kurang, sebenarnya anak tersebut bisa mendapat nilai baik, apabila pembelajaran seringkali diulang-ulang.

Hasil akhir menyimpulkan bahwa dengan cara permainan lego secara menarik, akan membantu pemahaman kognitif yang baik pula. 


\section{KESIMPULAN}

Gaya mengajar yang membosankan sering terjadi saat guru sedang mengajar anak didiknya. Hal ini disebabkan guru tidak pernah mengevaluasi proses pembelajarannya di kelas. Dampaknya anak didik tidak dapat konsentrasi kemudian merasa jenuh, sebal, bahkan membuat ulah dan bikin gaduh. Kalau pun tampak mendengarkan disebabkan karena faktor lain yaitu ketakutan. Dan akhirnya proses belajar mengajar pun tidak dapat maksimal.

Untuk itu guru perlu mengevaluasi proses pembelajaran di kelas. Penelitian Tindakan Kelas merupakan jalan yang tepat bagi guru untuk melakukan evaluasi dengan hasil akurat.

Penelitian Tindakan Kelas yang telah peneliti beri judul "Penggunaan Permainan lego Dalam Bidang Pengembangan Kognitif untuk Meningkatkan Kreativitas Anak Usia Dini di PPT Permata Bunda Kecamatan Wonocolo Surabaya”, agar dapat lebih meningkatkan daya pikir anak untuk lebih memahami konsep bilangan. Di samping itu membantu guru untuk meningkatkan profesionalisme, mengembangkan potensi diri, kreativitas, dan komitmen terhadap pengembangan profesinya, serta relatif guru tidak akan menemui kesulitan dalam proses pembelajaran. Karena dengan model pembelajaran yang tepat murid/ siswa akan senang mengikuti pembelajaran dan hasilnya pun memuaskan.

\section{SARAN}

\section{Bagi Sekolah}

a. Untuk lembaga pendidikan anak usia dini dapat menggunakan permainan lego untuk meningkatkan pengembangan kognitif dan meningkatkan kemampuan kreativitas pada anak usia dini. b. Anak belajar melalui bermain, dengan bermain anak mengembangkan kemampuannya dari pengalaman yang diperoleh melalui bermain.

\section{Bagi Peneliti Lain}

a. Penelitian ini dapat dijadikan sebagai acuan peneliti berikutnya khususnya pada kegiatan pembelajaran pengembangan kognitif untuk meningkatkan kreativitas anak usia dini melalui permainan-permainan yang menarik.

b. Fokus pada subjek penelitian di PPT Permata Bunda Kecamatan Wonocolo Surabaya diharapkan dapat diperluas dengan subjek yang lebih besar lagi dan latar belakang serta permasalahan yang berbeda.

\section{DAFTAR PUSTAKA}

Abdussalam. 2009. Aktivitas Bermain Bersama Anak Usia 3-6 tahun. Jakarta: Elex Media Komputindo.

Arikunto, dkk. 2010. Penelitian Tindakan Kelas, Jakarta: PT Bumi Aksara.

Arikunto, Suharsimi. 2006. Prosedur Penelitian. Jakarta: Rineka Cipta.

Broemley, K.D. 1992. Language Arts, Exploring Connection (2 ${ }^{\text {nd }}$ ed.) Boston: Allyn and Bacon.

Departemen Pendidikan dan Kebudayaan. 1992. Pedoman Penggunaan Alat Peraga Taman Kanak-Kanak.

Departemen Pendidikan dan Kebudayaan. 1995. Petunjuk Teknis Proses Belajar Mengajar di Taman Kanak-Kanak.

Departemen Pendidikan Nasional. 2007. Pedoman Pembelajaran Kognitif di Taman KanakKanak. Jakarta: Dirjen Manajemen Dikdasmen, Direktorat Pembinaan TK dan SD. 
Departemen Pendidikan Nasional. 2007. Permainan Berhitung di Taman Kanak-Kanak. Jakarta: Dirjen Dikdasmen Direktorat Dikdas.

Hughes, Fergus P. 1999. Children, Play and Development. London: Allyn \& Bacon.
Nurlaila N.Q. Mei Tientje, M.Pd., Dr. H. Yul Iskandar Ph.D. Pendidikan Anak Usia Dini (PADU) untuk Mengembangkan Multipel Inteligensi.

Susilo. 2007. Panduan Penelitian Tindakan Kelas. 